\title{
Advanced Bladder Cancer in Senegal: Epidemiological and Clinical Aspects
}

\author{
R. Kane ${ }^{1}$, L. Niang' ${ }^{2}$, Y. Diallo ${ }^{3}$, M. Jalloh ${ }^{2}$, A. Ndiaye1, S. M. Gueye ${ }^{2}$ \\ ${ }^{1}$ Service urologie hôpital principal, Dakar, Senegal \\ ${ }^{2}$ Service urologie hôpital general de grand yoff, Dakar, Senegal \\ ${ }^{3}$ Service urologie, Thiés, Senegal \\ Email: ${ }^{*}$ donekane2008@yahoo.fr
}

Received 29 August 2014; revised 18 September 2014; accepted 20 October 2014

Copyright (C) 2014 by authors and Scientific Research Publishing Inc.

This work is licensed under the Creative Commons Attribution International License (CC BY). http://creativecommons.org/licenses/by/4.0/

(c) (i) Open Access

\begin{abstract}
Advanced bladder cancer remains particularly frequent in our practice. Aim: To evaluate the proportion of advanced bladder cancer at diagnosis and to describe the characterisitics at diagnosis. Materials and methods: We conducted a descriptive and retrospective study assessing 97 cases of advanced bladder cancer over a period of 10 years (January 2002 to January 2012) at the department of Urology of Hôpital Principal de Dakar and Hôpital Général de Grand Yoff. We included the records of all patients with a pathologic confirmation of locally advanced bladder cancer (T3, T4) and/or a visceral or lymph node metastasis. Results: Mean age was 47 years (Range: 25 - 80 years). The cohort comprised 69 men and 28 women with a sex ratio of 2.46 . The reasons for referral were a hematuria $(60.82 \%)$, pelvic mass $(19.2 \%)$, irritative urinary symptoms $(8.2 \%)$. Reported medical histories were: urinary schistosomiasis (13 patients), tobaccoo(10 patients), recurrent cystitis (8 patients). Indications of local extention were: inguinal lymph nodes (6 patients), tumoral hepatomegaly ( 5 patients), bone pain (15 patients). A cystoscopy was performed in $64.95 \%$ of patients in a mean time of 2.5 months. A Trans Urethral Resection of Bladder Tumour (TURBT) was performed in $\mathbf{7 7}$ patients with a mean time from referral of 4 months. Pathologic examination showed squamous cell carcinoma (42\%), urothelial carcinoma $(28 \%)$ and adenocarcinoma (9\%). Thoraco-abdomino pelvic CT scan showed a loco regional extension in 18 patients, extension to the peri vesical fat in 3 patients and metastasis in 25 patients. Conclusion: Delayed diagnosis of bladder cancer is still common in Africa with a high mortality rate. A better management requires an improvement of the equipment in the hospital with an emphasis on the access to endoscopy allowing for an early diagnosis.
\end{abstract}

\section{Keywords}

Advanced Bladder Cancer, Schistosomiasis, Endoscopy

\footnotetext{
${ }^{*}$ Corresponding author.
}

How to cite this paper: Kane, R., Niang, L., Diallo, Y., Jalloh, M., Ndiaye, A. and Gueye, S.M. (2014) Advanced Bladder Cancer in Senegal: Epidemiological and Clinical Aspects. Open Journal of Urology, 4, 127-131. 


\section{Introduction}

Until 1984, bladder cancer was the most frequent cancer in Senegal [1], but in the recent years owing to the screening for prostate cancer and the reduction of the incidence of urogenital schistosomiasis, bladder cancer was the second most frequent cancer after prostate cancer. However, the diagnosis is still delayed in many African countries due to the consideration of hematuria and the difficult access to diagnostic tools [1].

The aim of the study was to determine the proportion of advanced bladder cancer at diagnosis and to perform a descriptive analysis of the epidemiology and clinical aspects.

\section{Patients and Methods}

We conducted a descriptive and retrospective study of all cases of advanced bladder cancer at the department of Urology of Hospital Principal de Dakar and Hopital General de Grand Yoff from January 2002 to January 2012. All patients with pathologic report indicating a locally advanced bladder cancer (T3, T4) or the presence of any visceral or lymph node metastasis irrespective of the local extent of the disease were included. We excluded all cases of localised disease (T1, T2) without a metastasis and the cases with no record of pathologic confirmation. The variables studied were:

- Sociodempgraphic data: (age, sex);

- Clinical data: (medical history, risk factors, reason for referral, clinical findings);

- Paraclinical data: (biology, endoscopy, imaging);

- Pathologic findings: (histological type, cancer stage);

- Extension of the disease based on clinical complains, X-Ray, abdominal Ultrasound, Cystoscopy, Thoraco abdominal CT-Scan and MRI.

Data were collected and analysed using epi-info version 3-5-1 software.

\section{Results}

During the study period, we identified 133 records of bladder cancer cases of which 97 (72\%) met the inclusion criteria. The series comprised 69 men and 28 women giving a sex ratio of 2.46.

Mean age was 47 years (range: 25 - 80 years). Age groups are represented in Figure 1.

Mean time to consultation was 6 months (Range: 20 days; 3 years).

Reasons for referral were: hematuria (60.82\%), irritative urinary symptoms (6.19\%), pelvic mass (19.2\%) as described by Figure 2 .

Reported medical history were urinary schistosomiasis (13 patients), smoking (12 patients)) and repeted cystitis (10 patients).

Physical examination found a urinary retention with a bladder globe in 26 patients, a pelvic mass in 18 patients (19.2\%), clinical anemia in 25 patients and a poor general condition in 26 patients.

Cystoscopy was performed in $64.95 \%$ of our patients within a period of 2.5 months. The macroscopic aspects at cystoscopy are presented by Table 1 and the location of lesions are summarised by Table 2 .

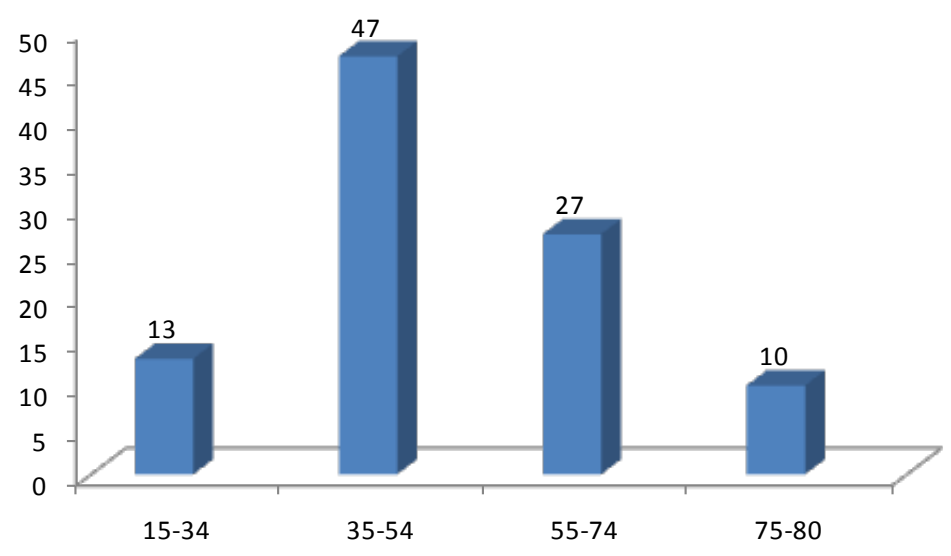

Figure 1. Distribution of patients by age groups. 


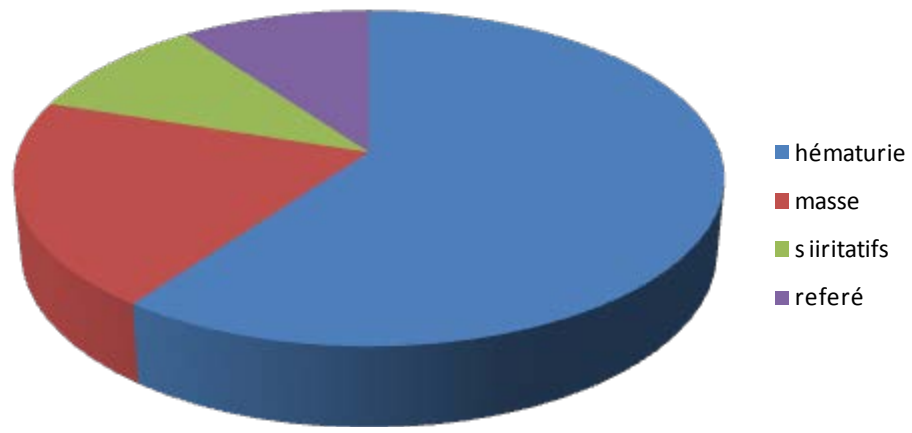

Figure 2. Distribution of patients by reason for consultation.

Table 1. Distribution of patients according to the aspect of the tumor to cystoscopy.

\begin{tabular}{ccc}
\hline Aspect des tumeurs & Effectifs & Pourcentage \\
\hline Bourgeonnante & 29 & $46.03 \%$ \\
Hémorragique & 9 & $14.29 \%$ \\
TV + Granulations réfringentes & 4 & $6.35 \%$ \\
Chevelue & 2 & $3.17 \%$ \\
Nécrotique & 5 & $7.94 \%$ \\
Plane & 1 & $1.59 \%$ \\
Polyploïde & 5 & $7.94 \%$ \\
Envahissement locorégional & 8 & $12.70 \%$ \\
Total & 63 & $100.00 \%$ \\
\hline
\end{tabular}

Table 2. Distribution of patients according to the tumor site cystoscopy.

\begin{tabular}{ccc}
\hline Siege des tumeurs & Effectifs & Pourcentage \\
\hline Trigone & 9 & $14.29 \%$ \\
Dôme & 3 & $4.76 \%$ \\
Col & 6 & $9.52 \%$ \\
Paroi latérale & 11 & $17.46 \%$ \\
Paroi antérieure & 4 & $6.35 \%$ \\
Paroi postérieure & 5 & $7.94 \%$ \\
Multiple & 14 & $22.22 \%$ \\
Siège non précisé & 11 & $17.46 \%$ \\
Total & $\mathbf{6 3}$ & $\mathbf{1 0 0 . 0 0 \%}$ \\
\hline
\end{tabular}

A TURBT was performed in 77 patients within a period of 4 months. Pathology examination of the specimen showed squamous cell carcinoma (42\%), urothelial carcinoma (28\%) and adenocarcinoma (9\%).

TURBT was not performed for 20 patients for different reasons: poor general condition (13 patients), hemodynamic instability (2 patients), patient refusal (2 patients) and important loco regional extension (3 patients).

The evaluation of the disease extension showed at imaging: inguinal lymphadenopathy (6 patients), tumoral hepatomagaly (5 patients), pulmonary metastasis (5 patients), bone metastasis (7 patients) and ascitis (2 patients). Thoraco abdominal CT scan showed a loco regional extension (18 patients), an extension to the perivesical fat (3 patients) and metastasis (25 patients).

\section{Discussion}

Mean age of our patients was 47 years (Range: 25 - 80 years) and the most represented age group was 35 - 54 
years. However $40 \%$ of our patients were under 50 years. Our findings are consistent with the results published by Niang L et al. [2], Diao B et al. [1] in Senegal and other African series [3]-[5] indicating a mean age in the 50 '. The young age of our patients contrasts with the findings of western series indicating a late onset of bladder cancer over 60 years [6]-[8].

Bladder cancer is more frequent in men. We report a sex ratio of 2.46 which is consistent with the findings of Diao B et al. [1] and Niang L et al. [2] in Senegal with a respective sex ratio of 1.23 and 3, as well as European series with Guillotreau J et al. [6] and Polleto B [8] finding respectively a sex ratio of 3 and 2.

The major risk factor appearing in our study is urogenital schistosomiasis. The prevalence of schistosomiasis could even be higher if more investigations were carried out in the 21 other patients with a report of a history of hematuria.

These findings are consistent with the data of Tangara S. [9] in Mali showing a history of schistosomiasis in $80 \%$ of patients and the results of Guirou A. [3] indicating a proportion $48.84 \%$. Urinary schistosomiasis is endemic in 53 African countries including Senegal [10] and 70 millions of people are estimated to suffer from the disease. Schistosmiasis and chronic cystitis are associated with squamous cell carcinoma of the urinary bladder [1] [4] [9] [11].

Hematuria is the major symptom. It was present in $61.1 \%$ of our patients. However, despite its high frequency, this symptom is often not alarming for the African population and does not lead to an early consultation. This situation partly explains the advanced stage of the majority of cases at diagnosis.

The mean time to referral was approximately 6 months (Range: 1 month - 5 years). Tanagara S. [9] and Guirou Al. [3] in Mali reported a time to referral respectively ranging from 2 months to 5 years and 1 month to 12 years. Amegbor K. [12] in Togo found a mean time to referral of 8.6 months (Range: 2 - 60 months).

The findings at physical examination in our study such as bladder globe and pelvic mass already indicate an advanced stage of the cancer and more generally the symptoms encountered in Africa usually indicate an advanced disease. This is reflected by the fact that our cohort represents $72 \%$ of the bladder cancer cases followed up in our study period. Amegbor K. [12] reported that $66.7 \%$ of the cases presented a pelvic mass in Togo. Pelvic mass was also found in the series of Guirou A. [3] and Tanagara et al. [9] at a respective proportion of $43.71 \%$ and $56 \%$.

The multiple metastasis found in our study along with the long and slow evolution of the disease are consistent with the late referral. Such a feature is common in most African series. That is the case of the findings reported by Malle M.N. [13] showing an extension to the external genitalia in $20 \%$ of cases, a lymph node involvement in $4.64 \%$ of patients and lower limbs oedema in $2.23 \%$ of cases. Guirou [3] found a liver mass indicating a metastasis in $1.16 \%$ of cases.

The management of our patients is limited by the lack of diagnostic equipments.

Cystoscopy was performed in 63 of our patients (64.94\%) which underscore the limited access to this examination for the population wether in terms of cost or in terms of the availability in the hospitals. The time from the referral to the cystoscopy was therefore too long in our series (mean: 2.5 months) and did not contribute to the diagnosis in most of the African series [3] [4].

TURBT is the key procedure for the diagnosis but it also poses the problem of limited access. The long time to the performance of the TURBT (mean: 4 months) explains the high number of patients who did not undergo this procedure. Of the 20 patients without TURBT, we noted 2 cases of refusal but the majority of the patients had a poor general condition, consequence of the advanced stage of the disease. In the other African series, TURBT was not reported.

Because of its accessibility, ultrasound is still largely performed at first intent in African series [3] [4] [9]. More than half of the patients in our series underwent CT scan but because of its high cost, it is not routinely ordered in many African countries [3] [4] [9]. In the series of Malle N.M. [13] and Tangara S. [9] anly 2 and 1 patients respectively underwent a CT scan.

Squamous cell carcinoma was the commonest pathologic finding which is consistent with other reports from Senegal [1] [2]. In Burkina Faso, Diednere E et al. [4] reported $60.30 \%$ of squamous cell carcinoma while in Mali this proportion was $69.23 \%$ and $80 \%$ in the reports of Malle N.M. [13] and Guirou A. [3] respectively. Desgrippes A et al. [11] and Rischman P et al. [14] explain the high prevalence of squamous cell carcinoma in Africa by two factors: black race and the presence of urogenital schistosomiasis which is the case Senegal where schistosomiasis is endemic. The role of schistosomiasis in the occurence of squamous cell carcinoma of the bladder was raised by Fergusson A.R. [15] since 1911 because of the observation of a high incidence of bladder 
cancers in Egyptians presenting a urogenital schistosomiasis.

\section{Conclusion}

Bladder cancer occurs mostly in young patients with an advanced stage in Sénégal. The management is limited by the accessibility to endoscopic equipments for the diagnosis. Schistosomiasis remains an important risk factor despite the campaign against this endemy initiated about 15 years ago.

\section{References}

[1] Diao, B., Amath, T., Fall, B., Fall, P.A., Dieme, M.J., Steevy, N.N., et al. (2008) Les cancers de vessie au Sénégal: Particularités épidémiologiques, cliniques et histologiques. Progrès en urologie, 18, 445-448. http://dx.doi.org/10.1016/j.purol.2008.04.016

[2] Niang, L., Kane, R., Labou, I., Jalloh, M., Ndoye, M., Konte, K.A., et al. (2011) Cystectomies totales pour cancers localement avancés de vessie au service d’urologie de l’hôpital général de Grand-Yoff. Progrès en urologie, 21, 121125. http://dx.doi.org/10.1016/j.purol.2010.06.002

[3] Guirou, A. (2007) Prise en charge des tumeurs de vessie dans le service d'urologie du CHU du point G. Th. Med. Bamako: Université de Bamako. Faculté de médecine de pharmacie et d’odontostomatologie, 86 p.

[4] Diednere, E. (1996) Le cancer de la vessie au Burkina: Étude anatomo-clinique de 83 cas. Th. Med. Ouagadougou: Université de Ouagadougou. Faculté des sciences de la santé, section médecine, No. 4, 92 p.

[5] Ouattara, A., Hodonou, R., Avakoudjo, J., Cisse, D., Zango, B., Gandaho, I., et al. (2012) Epidémiologie des cancers urologiques au centre hospitalier universitaire Hubert Koutoukou Maga Cotonou, Bénin. Analyse d’une série hospitalière de 158 cas. Progrès en urologie, 22, 261-265. http://dx.doi.org/10.1016/j.purol.2011.12.003

[6] Guillotreau, J., Game, X., Mouzin, M., Roche, J.-B., Abu Anz, S., Doumerc, N., et al. (2010) Cystectomie radicale cœlioscopique pour cancer de vessie, chez les sujets de plus de 70 ans : faisabilité et étude de la morbidité. Progrès en urologie, 20, 204-209. http://dx.doi.org/10.1016/j.purol.2009.08.040

[7] Braud, G., Battisti, S., Karam, G., Bouchot, O. and Rigaud, J. (2008) Mortalité et morbidité des cystectomies totales pour cancer de la vessie chez les patients de plus de 75 ans. Progrès en urologie, 18, 1062-1066.

http://dx.doi.org/10.1016/j.purol.2008.07.009

[8] Polleto, B. (2011) InfoCancer. In: Association Pour la recherche sur le cancer notamment Gynécologique (ARCAGY). [En ligne]. Paris, 2011. Disponible sur:

http://www.arcagy.org/infocancer/localisations/rein-et-voies-urinaires/cancer-vessie/traitements/la-chirurgie.html

[9] Tangara, S. (2008) Eude des tumeurs de vessie au service d'urologie du centre hospitalier universitaire Gabriel Toure à propos de 50 cas. Th. Med. Bamako: université de Bamako. Faculté de médecine, de pharmacie et d’odonto stomatologie. CHU Gabriel Touré, 92 p.

[10] Senghor, B. (2010) Prévalence et intensité d'infestation de la bilharziose uro-génitale chez des enfants d'âge scolaire à Niakhar (milieu rural sénégalais). [en ligne]. D.E.A. Bio. Dakar. Université Cheikh AntaDiop de Dakar. Faculté des sciences et techniques, No. 278, 100 p.

[11] Desgrippes, A., Meria, P., Cortesse, A., Cochand-Priollet, B. and Cariou, G. (1998) Carcinomes épidermoïdes de la vessie. Progrès en Urologie, 8, 321-329.

[12] Amegbor, K. (2010) Les tumeurs de vessie au Togo: Aspects épidémiologiques et diagnostiques à propos de 36 cas observés au CHU de Lomé. Annales de pathologie, 30, 68-69. http://dx.doi.org/10.1016/j.annpat.2009.10.019

[13] Malle Noumou, M. (2009) Etude clinique des tumeurs de vessie dans le service d’urologie du C.H.U du point “G” à propos de 40 ans. [en ligne].

[14] Rischmann, P., Mazerolles, C., Baron, J-C., Chopin, D., Davin, J.-L., Davin, L., et al. (2000) Tumeurs malignes rares de la vessie-tumeur malignes de l'urètre, 10, 16-34. Disponible sur: http://www.urofrance.org/fileadmin/documents/data/C2/2000/C2-2000-00100015-4/TEXF-C2-2000-00100015-4.PDF

[15] Ferguson, A.R. (1911) Associated Bilharziasis and Primary Malignant Disease of the Urinary Bladder with Observations on a Series of Forty Cases. The Journal of Pathology and Bacteriology, 16, 76-94.

http://dx.doi.org/10.1002/path.1700160107 
Scientific Research Publishing (SCIRP) is one of the largest Open Access journal publishers. It is currently publishing more than 200 open access, online, peer-reviewed journals covering a wide range of academic disciplines. SCIRP serves the worldwide academic communities and contributes to the progress and application of science with its publication.

Other selected journals from SCIRP are listed as below. Submit your manuscript to us via either submit@scirp.org or Online Submission Portal.
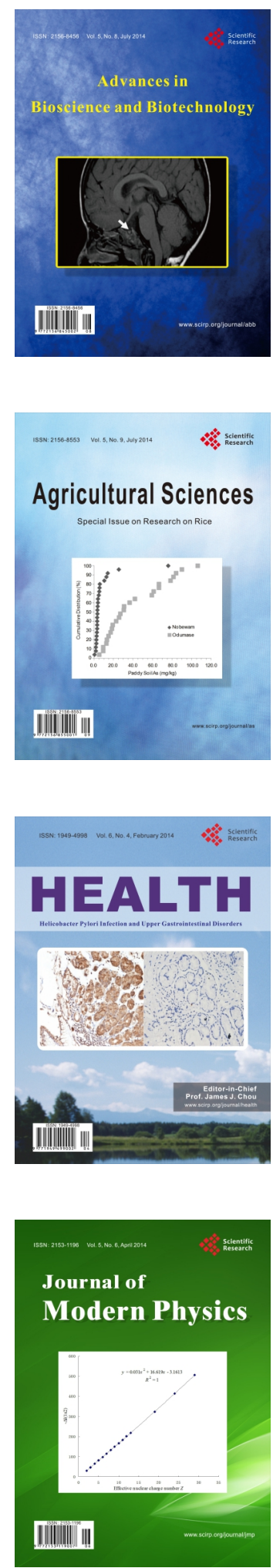
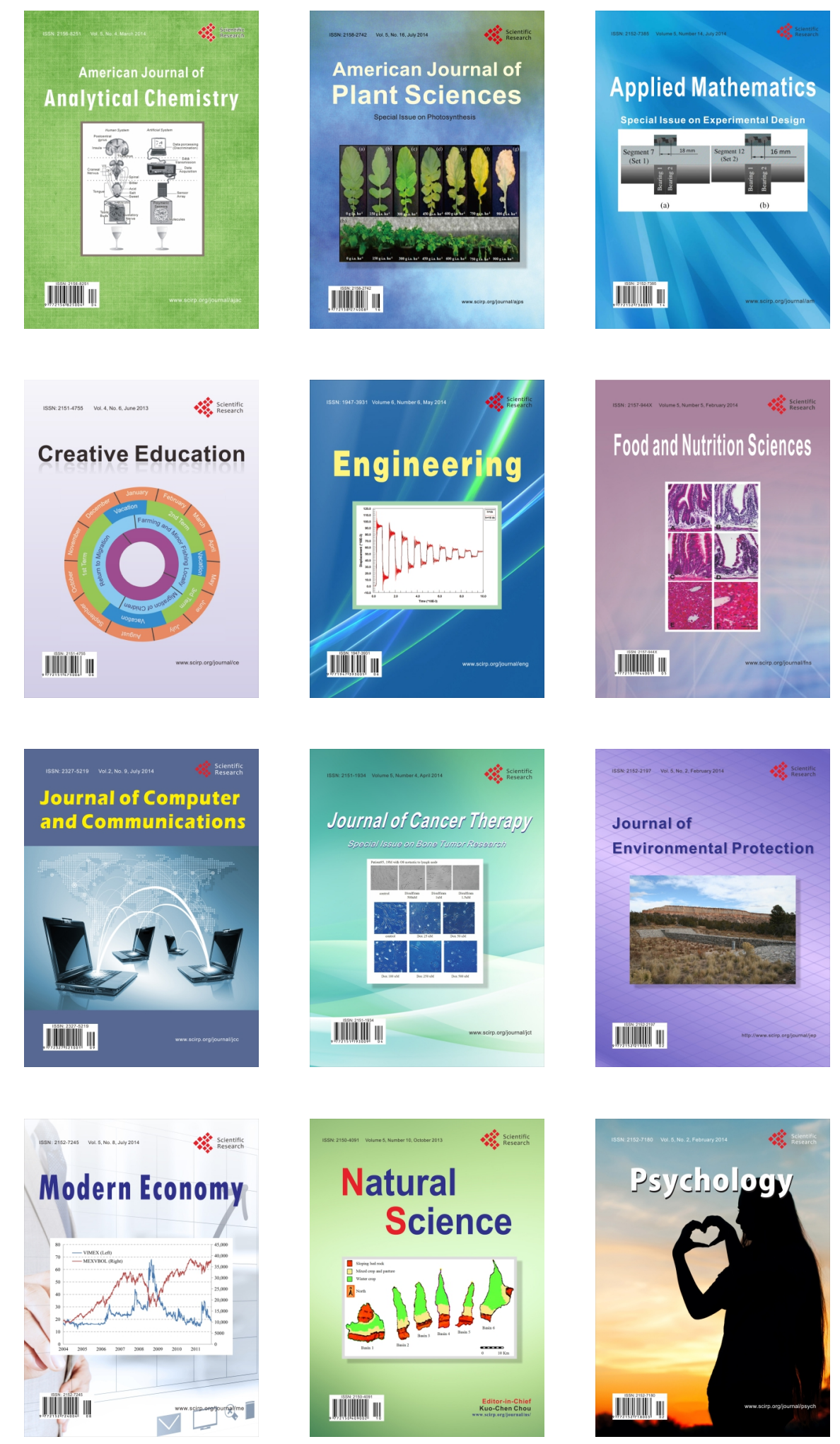